\title{
Response in nutritionally related blood metabolites, carcass traits and primal pork cuts of slow growing Windsnyer pigs fed on varying levels of potato hash silage
}

\author{
C.N. Ncobela ${ }^{1,2}$, A.T. Kanengoni $i^{3,4} \&$ M. Chimonyo ${ }^{1 \#}$ \\ ${ }^{1}$ Animal and Poultry Science, School of Agricultural, Earth and Environmental Sciences, University of KwaZulu-Natal, P \\ bag X01 Scottsville 3209, Pietermaritzburg, South Africa \\ ${ }^{2}$ Agricultural Research Council-Animal Production Institute (Nutrition Building), Private Bag X 2, Irene 0062, South Africa \\ ${ }^{3}$ Veterinary services and Research Department, Joburg Zoo, Private Bag X13, Parkview, 2122 \\ ${ }^{4}$ College of Agriculture and Environmental Sciences, University of South Africa, Florida Campus, Florida, South Africa
}

(Received 27 January 2018; Accepted 25 June 2018; First published online 18 September 2018)

Copyright resides with the authors in terms of the Creative Commons Attribution 4.0 South African License. See:
http://creativecommons.org/licenses/by/4.0/za

\begin{abstract}
The response of Windsnyer pigs to diets containing varying levels of potato hash silage in nutritionally related blood biochemistry, carcass traits and primal pork was estimated. Thirty-six growing clinically healthy male Windsnyer pigs with an initial weight of $36 \mathrm{~kg} \pm 4.89$ (mean \pm standard deviation (SD)) were randomly assigned to six experimental diets containing $0,80,160,240,320$, and 400 potato hash silage g/kg dry matter (DM). Experimental diets were derived from mixing a summit diet containing no potato hash silage and a dilution diet containing $400 \mathrm{~g}$ potato hash silage/ $\mathrm{kg}$ in various proportions. Pigs were allowed ad libitum access to diets and water. There was no relationship between inclusion levels of potato hash silage and albumin: globulin ratio, total protein, and uric acid. As inclusion levels of potato hash silage varied, there was a positive linear relationship between silage and albumin concentration. Globulin concentration had a positive quadratic relationship with the inclusion of potato hash silage. Inclusion levels of potato hash silage resulted in a positive quadratic relationship in alkaline phosphatase. There was a negative linear response in warm carcass weight and cold carcass weight to inclusion levels of silage. A negative linear response was observed in dressing percentage. Different inclusion levels of potato hash silage caused a positive quadratic relationship in cooler shrink. There were negative linear relationships between inclusion of potato hash silage with shoulder fat, carcass length and backfat thickness. There was a negative linear relationship between eye muscle area and inclusion level of ensiled potato hash. There was a positive quadratic relationship between hindquarter length (HQL) and inclusion levels of silage. The observed linear relationship between hindquarter circumference (HQC) and inclusion levels of potato hash silage was negative. There is a need to predict the optimum inclusion level of potato hash silage without compromising the healthiness and carcass yield of pigs.
\end{abstract}

Keywords: Alkaline phosphatase, backfat thickness, cold carcass weight, cooler shrink, dorsal fat thickness, eye muscle area, hindquarter circumference, total protein

\# Corresponding author: E-mail: chimonyo@ukzn.ac.za

\section{Introduction}

Sub-Saharan Africa has widespread populations of autochthonous pigs that are kept under extensive production systems that could benefit from potato by-product diets, among which is the South African Windsnyer pig (Kanengoni et al., 2014). This breed has a black coat, a compact body, small body structure, and a long nose. Windsnyer pigs enjoy several attributes under extensive production systems that make them ideal for enhancing food security. These include resistance to endemic diseases, excellent fertility, the ability to survive feed shortages, the facility to use locally available feeds, the capacity to withstand extremes of temperature and to utilize superior scavenging habits (Chimonyo et al., 2001). Windsnyer pigs thus need an environment that is conducive to growth and reproduction at optimum levels. The promotion on the market of organically produced pork from slow-growing pigs might enhance the choices for the increasingly 
health-conscious population (Madzimure et al., 2017). The Windsnyer pig is being ignored for a number of reasons. For example, its carcasses do not satisfy the requirements of grading schemes that focus on lean meat production (Halimani et al., 2012). Even so, high subcutaneous fat deposition, which is found in the carcasses of Windsnyer pigs, is a resource for smallholder pig farmers. Farmers use it as lard for cooking (Ncobela et al., 2017) and body lotion. Windsnyer pigs are also excluded owing to their small frames and compact body structures that are deemed to produce inadequate pork for the increasing human population. However, a small frame is an advantage to smallholder pig farmers who frequently experience pig feed shortages. There is, therefore, a need to develop a strategy for smallholder pig farmers to benefit optimally from the production of Windsnyer pigs without boundaries. Utilizing slow-growing pigs that are adapted to local environmental conditions enhances the sustainability of these systems.

Slow-growing pigs are likely to be replaced by imported breeds if their meritorious attributes are not exploited. To stress conservation and intensify the production of Windsnyer pigs while exploiting fibrous and high-moisture feed ingredients, it is crucial to determine the healthiness and toxicity of these feed ingredients to Windsnyer pigs. It is also important to determine the ability of Windsnyer pigs to convert fibrous and highmoisture diet to pork products. Windsnyer pigs utilize locally available fibrous feedstuffs efficiently and require minimal financial input for production (Kanengoni et al., 2014). Potato hash is a by-product that is derived from the production of snacks and chips. It is plentiful and could be used as a cheap alternative feed resource for pigs kept under extensive production systems. It is preserved and used in the form of silage owing to its high moisture content, which shortens its shelf life. Dry absorbents such as maize cobs are used to ensile potato hash because it has high water content. Ensiling potato hash is practical and economically feasible for smallholder pig farmers. There is a dearth of information about the contribution of ensiling to the toxicity of potato hash silage. Potato hash contains plant steroids called glycoalkaloids, which exert toxic effects on the nervous system by interfering with the body's ability to regulate acetylcholine, a chemical that is responsible for conducting nerve impulses (Cantwell, 1996).

Fang et al. (2014) reported that diets that are high in dietary fibre and have potato-resistant starch increase volatile fatty acid concentration in the gut, modulate host gene expression, and eventually influence the adipose metabolism, backfat thickness and pork quality. However, data is limited on dose-response trials that evaluate the relationship between ensiled potato hash silage and carcass traits and primal cuts of pork from Windsnyer pigs. The objective of the study was to determine the response in nutritionally related blood metabolites, carcass traits and primal pork cuts of pork from slow-growing Windsnyer pigs fed on graded levels of potato hash silage. It was hypothesized that this response is related in a positive linear fashion to the inclusion levels of potato hash silage.

\section{Materials and Methods}

The study was conducted at Agricultural Research Council (ARC)-Irene, Animal Production Institute, South Africa. The institute is situated at $25^{\circ} 34^{\prime} 0^{\prime \prime} \mathrm{S}$ and $28^{\circ} 22^{\prime} \mathrm{O}^{\prime \prime} \mathrm{E}$ and is approximately $1526 \mathrm{~m}$ above sea level. The average annual temperature when the study was conducted was $19.9^{\circ} \mathrm{C}$. The use and care of the experimental animals were ethically approved (reference number APIEC16/015) by the ARC Animal Production Institute Ethics Committee.

Thirty-six clinically healthy male growing Windsnyer pigs with an average initial bodyweight of $35.2 \mathrm{~kg}$ \pm 4.89 (mean \pm SD) were selected from the indigenous pig section of the ARC. The pigs were aged between three and four months and were already exhibiting signs of sexual maturity. The pigs were moved from the indigenous pig section, where they were housed in groups, to a trial facility where they were penned individually in a completely randomized design. The housing facility was cleaned thoroughly and disinfected a week before the trial was undertaken. The area surrounding the experimental house was also cleaned. The temperature and relative humidity in the experimental house were maintained at $24.5\left( \pm 1.9^{\circ} \mathrm{C}\right)$ and $62.7 \%( \pm 15.07 \%)$, respectively. Six pigs were randomly assigned to each experimental diet. An environmental facility and dietary acclimatization period of seven days were allowed for pigs before data collection commenced. Feed and water were available ad libitum. The feeding trial lasted six weeks. Average daily feed intakes of pigs fed on $0,80,160,240,320$, and $400 \mathrm{~g} / \mathrm{kg}$ potato hash silage were 1.38 , 1.47, 1.54, 1.55, 1.41, and $1.39 \mathrm{~kg}$, respectively (Ncobela et al., 2018). The slaughter weight was $36 \pm 4.66$ $\mathrm{kg}($ mean $\pm \mathrm{SD})$.

Fresh potato hash was collected from Simba ${ }^{\circledR}$, a local food-producing company. The potato hash was blended with ground maize cobs to increase the DM content to between $250 \mathrm{~g} / \mathrm{kg}$ and $400 \mathrm{~g} / \mathrm{kg}$ for good quality silage. The potato hash to maize cob mixture was in the ratio of $70: 30 \mathrm{~g} / \mathrm{kg}$, respectively. The potato hash mixture was then ensiled by compacting it in $210 \mathrm{~L}$ drums lined with polyethylene plastic bags. After compaction, the plastic bags were knotted and tightened to prevent aerobic conditions. The drums were closed with rubber lids to prevent damage to the bags by rodents and were stored at temperatures ranging from $22{ }^{\circ} \mathrm{C}$ to $29^{\circ} \mathrm{C}$. The silage drums were opened weekly after mixing the diets to prevent spoilage. 
A total mixed ration without silage was formulated to meet or exceed the nutritional requirements of growing Windsnyer pigs (Carter et al., 2016) and was used as a basal or summit diet (Ncobela et al., 2018). A bulky diet containing $400 \mathrm{~g}$ silage per $\mathrm{kg}$ was also formulated and used as the dilution diet (Ncobela et al., 2018). Six diets containing $0,80,160,240,320$, and $400 \mathrm{~g} / \mathrm{kg}$ of silage were produced by mixing the summit and dilution diets in various proportions as described by Gous \& Morris (1985), namely 100:0, $80: 20,60$ : $40,40: 60,20: 80$, and $0: 100$.

Samples of all diets and potato hash silage were collected and analysed in triplicate (Ncobela et al., 2018). Procedures from the Association of Official Analytical Chemists (AOAC, 2005) were used to determine dry matter (DM), (ID (identity) 2001.12), ash (ID 942.05), crude protein (CP) (ID 990.03) and ether extract (EE) (ID 963.15). Neutral detergent fibre (NDF) and acid detergent fibre (ADF) were determined according to ANKOM technology method (Van Soest et al., 1991). The NDF content was assayed using heat stable a-amylase (Sigma A3306, Sigma Chemical Co., St. Louis, MO, USA). Digestible energy (DE) of potato hash silage and experimental diets were calculated from the equation adapted from McDonald et al. (2010):

Digestible energy $(\mathrm{MJ} / \mathrm{kg})=17.47+(0.0076 \times \mathrm{CP} \mathrm{g} / \mathrm{kg})+(0.0158 \times$ acid hydrolysed ether extract $\mathrm{g} / \mathrm{kg})$ - $(0.0331 \times$ ash $\mathrm{g} / \mathrm{kg})-(0.0140 \times \mathrm{NDF} \mathrm{g} / \mathrm{kg})$

The bulk density of the diets and silage was measured using the water displacement method, as described by Kyriazakis \& Emmans (1995). The water-holding capacity of diets was measured using the centrifugation method as described by Whittemore et al. (2003). Swelling capacity was measured according to Canibe \& Bach Knudsen (2002). A $10 \mathrm{ml}$ blood sample was collected through jugular venipuncture in noncoagulated vacutainer tubes (Becton Dickinson, Franklin, $\mathrm{NJ}$ ) to determine nutritionally related blood metabolites and liver enzymes (Weicheselbaum, 1946; Kanengoni et al., 2014). Two blood samples were collected from each pig. This was done on the last day of the feed intake and growth performance experiment (Ncobela et al., 2018).

Pigs were transported to an abattoir situated at about $1.5 \mathrm{~km}$ from the trial facility at 08:30. Pigs were treated humanely according to routine abattoir protocols, which included ante-mortem inspection. Procedures for stunning, exsanguination, de-hairing, evisceration and cutting were sourced from Kanengoni et al. (2014). Warm carcass weight, cold carcass weight, cooler shrink, and ultimate $\mathrm{pH}\left(\mathrm{pH}\right.$ at $\left.24 \mathrm{~h}\left(\mathrm{pH}_{24}\right)\right)$ were determined according to Schweihofer (2011) and Kanengoni et al. (2014). Backfat thickness was taken at the first rib (dorsal fat thickness at first rib (DFT1)), last rib (dorsal fat thickness at last rib (DFT2)), and last lumbar vertebra (dorsal fat thickness at last lumbar vertebra (DFT3)) off the median plane cut surface and measured in accordance with Kanengoni et al. (2014). The eye muscle area (EMA) was estimated using the formula proposed by Zhang et al. (2007):

$E M A=E M L \times E M W \times 0.7$.

Where: EMW was the average of the three width measurements of the eye muscle, and

EML was the eye muscle length

The standard measurement of and calculations for drip loss were fully explained by Kanengoni et al. (2014). The measurements for HQL, HQC and for rip weight proportion (RWP), shoulder weight proportion (SWP) and hindquarter weight proportion (HQWP) were carried out according to Kanengoni et al. (2014).

The PROC UNIVARIATE procedure of SAS, (2008) was used to establish the normality of the data. The data were normally distributed. A PROC MEANS (SAS, 2008) procedure was then used to determine the mean \pm SE (standard error) for inclusion level of silage against nutritionally related blood metabolites, carcass traits and primal pork cuts of Windsnyer pigs. A polynomial regression (PROC REG) procedure (SAS, 2008) was used to determine the relationships between inclusion levels of ensiled potato hash and nutritionally related blood metabolites, carcass traits and primal pork cuts. The regression was run on raw data. The model was:

$Y=B o+B_{1} A+B_{2} A^{2}+E$

Where: $Y=$ is the response variable (nutritionally related blood metabolites, carcass traits and primal pork cuts)

Bo = intercept

$\mathrm{B}_{1} \mathrm{~A}=$ linear regression component

$B_{2} A^{2}=$ quadratic regression component

$E=$ error 


\section{Results}

The relationships between inclusion levels of silage and nutritionally related blood metabolites are depicted in Table 1. Inclusion levels of silage influenced albumin and globulin concentrations. Albumin concentration was numerically higher than the normal range. The globulin concentration, on the other hand, was relatively lower than normal. There was no relationship between inclusion levels of silage and albumin, namely globulin ratio, total protein $(\mathrm{g} / \mathrm{dL})$ and uric acid $(\mathrm{mg} / \mathrm{dL})$. There was a positive linear relationship $(P$ $<0.05)$ between ensiled potato hash and albumin concentration. The activity of alkaline phosphatase was related to inclusion levels of silage. There was a positive linear $(P<0.001)$ relationship between alkaline phosphatase and inclusion levels of silage.

The relationship between inclusion levels of silage and carcass traits is shown in Table 2. There was a negative linear decrease $(P<0.001)$ in warm carcass weight. Various levels of silage also caused a negative linear $(P<0.001)$ response in cold carcass weight. A negative linear $(P<0.05)$ response in dressing percentage was observed when pigs were fed varying levels of silage. The cooler shrink showed a positive quadratic response $(P<0.05)$ to levels of silage. There was a negative linear relationship $(P<0.05)$ between inclusion levels of silage and carcass length. Shoulder fat also exhibited a negative linear relationship $(P$ $<0.05)$ with inclusion levels of silage. There was a negative linear $(P<0.01)$ response in eye muscle area with inclusion of silage. Drip loss and $\mathrm{pH}_{24}$ were not related $(P>0.05)$ to levels of silage. The response in primal pork cuts of Windsnyer pigs fed on levels of silage is portrayed in Table 3 . There was a positive quadratic relationship $(P<0.05)$ between $\mathrm{HQL}$ and inclusion levels of silage.

Hindquarter circumference showed a negative linear $(P<0.05)$ relationship with inclusion levels of silage. There was a negative linear relationship $(P<0.05)$ between DFT2 and inclusion levels of silage. DFT3 exhibited a linear decrease $(P<0.05)$ in relation to silage. Figure 1 shows the relationship between inclusion levels of silage and backfat thickness. There was a negative linear response $(P<0.01)$ in backfat thickness to inclusion levels of silage.

\section{Discussion}

The characterization of the Windsnyer pig's ability to utilize local by-products such as silage is dependent on determining the response of their blood metabolites to these by-products, because it is meaningless to utilize abundant local feedstuffs that are toxic and detrimental to pigs. Thus, determining changes in nutritionally related blood biochemistry is crucial. Serum albumin is a protein that is produced by the liver. It regulates fluid from leaking out of blood vessels, nourishes tissues, and transports hormones, vitamins, drugs, and substances such as calcium throughout the body. The positive linear relationship between inclusion levels of silage and albumin was unexpected. A negative response in albumin was anticipated because pigs that received diets containing high levels of silage had lower gain to feed ratio and scaled average daily gain (Ncobela et al., 2018). It is therefore difficult to draw a solid conclusion about the relationship between albumin and silage. A positive linear response in albumin concentration could mean that factors such as physiological and hormonal status were more sensitive and specific than a change in nutritional status. High albumin concentration with silage could be related to unsatisfied feed intake caused by a reduction in palatability. Higher albumin concentration than normal suggests that pigs were stressed by an inherent property of silage. Ensiled potato hash spoils over time after being exposed to aerobic conditions (Nkosi et al., 2010). In the present study, pigs that were fed on high levels of silage refused to eat when feed remained overnight (Ncobela et al., 2018). This may also lead to physiological changes such as high levels of stress hormone. Silage diets should be fed gradually. Slow-growing pigs such as the Windsnyer reach sexual maturity as early as three to four months (Chimonyo et al., 2001). Therefore, the increasing albumin concentration in the present study could be caused by pigs starting to become sexually mature. Another possible reason is that a marked increase in albumin concentration could indicate an unidentified virtue that allows pigs to utilize protein from high fibre diets efficiently.

Globulins are globular proteins that are insoluble in pure water, but dissolve in dilute salt solutions. Globulins are excreted from the liver. They help the immune system to fight against infection. A positive quadratic relationship between silage and globulin is difficult to explain. Slow-growing pigs are hardy and resistant to disease and parasites (Zanga et al., 2003; Mohlatlole et al., 2013). This could explain high levels of globulin in Windsnyer pigs. Inclusion of silage did not influence the serum total protein, which is an indirect index that indicates nutritional protein adequacy (Khanyile et al., 2017). Uric acid was not affected by inclusion levels of silage, but it was low (Radostits et al., 2000). Low uric acid concentration, which indicates protein catabolism, suggests sufficient protein consumption (Hlatini \& Chimonyo, 2016). The activity of alkaline phosphatase could be used to assess the health of the liver as it originates from osteoblasts and some is excreted in bile (Khanyile et al., 2017). A positive linear response in the activity of alkaline phosphatase to inclusion levels of silage implies that a reduction in the palatability of silage frustrated pigs. 
Table 1 Relationship between inclusion levels of potato hash silage and nutritionally related blood metabolites of Windsnyer pigs

\begin{tabular}{|c|c|c|c|c|c|c|c|c|c|c|c|}
\hline \multirow{2}{*}{ Variable } & \multirow{2}{*}{$\begin{array}{l}\text { Normal } \\
\text { ranges }\end{array}$} & \multicolumn{6}{|c|}{ Mean values for silage inclusion level (g/kg DM) } & \multirow{2}{*}{ SEM } & \multicolumn{2}{|c|}{$\begin{array}{c}\text { Regression co- } \\
\text { efficient }\end{array}$} & \multirow{2}{*}{$\begin{array}{c}\begin{array}{c}\text { Polynomial } \\
\text { regression }\end{array} \\
\text { Significance levels }\end{array}$} \\
\hline & & 0 & 80 & 160 & 240 & 320 & 400 & & Quadratic & Linear & \\
\hline Albumin (g/dL) & 1.8-3.3 & 4.46 & 4.79 & 4.42 & 4.47 & 4.83 & 5.19 & 0.181 & & 2.545 & * \\
\hline Globulin (g/dL) & $3.9-6.0$ & 2.98 & 3.35 & 3.56 & 3.96 & 3.14 & 2.66 & 0.132 & 0.0199 & & * \\
\hline Albumin : globulin ratio & - & 2.20 & 2.03 & 2.09 & 1.89 & 2.19 & 2.75 & 0.126 & & & NS \\
\hline Total protein (g/dL) & $6.0-8.0$ & 7.44 & 8.14 & 7.98 & 8.43 & 7.97 & 7.85 & 0.194 & & & NS \\
\hline Uric acid (mg/dL) & $\mathrm{N} / \mathrm{F}$ & 0.39 & 0.52 & 0.28 & 0.48 & 0.58 & 0.33 & 0.101 & & & NS \\
\hline Alkaline phosphatase (units/litre) & $92-294$ & 49.0 & 55,6 & 71,8 & 75,4 & 71,8 & 69.0 & 0.269 & & 4.83486 & * \\
\hline
\end{tabular}

${ }^{\star \star \star} P<0.001 ;{ }^{* \star} P<0.01 ;{ }^{*} P<0.05$; NS: not significant, N/A: not applicable; N/F: not found. SEM: standard error of mean

Normal ranges were sourced from Kanengoni et al. (2014)

Table 2 Relationship between inclusion levels of potato hash silage and carcass traits of slow-growing Windsnyer pigs

\begin{tabular}{|c|c|c|c|c|c|c|c|c|c|c|}
\hline \multirow{2}{*}{ Variable } & \multicolumn{6}{|c|}{ Mean values for silage inclusion level (g/kg DM) } & \multirow{2}{*}{ SEM } & \multicolumn{2}{|c|}{ Regression co-efficient } & \multirow{2}{*}{$\begin{array}{c}\text { Polynomial regression } \\
\text { Significance levels }\end{array}$} \\
\hline & 0 & 80 & 160 & 240 & 320 & 400 & & Quadratic & Linear & \\
\hline Warm carcass weight $(\mathrm{kg})$ & 39.1 & 33.7 & 28.7 & 29.9 & 30.3 & 23.7 & 2.72 & & -7.001 & $\star \star *$ \\
\hline Cold carcass weight $(\mathrm{kg})$ & 37.8 & 32.9 & 27.6 & 28.8 & 28.7 & 22.8 & 2.58 & & -6.78 & $\star \star \star ~$ \\
\hline Dressing percentage (\%) & 75.6 & 73.1 & 71.1 & 72.8 & 69.8 & 69.1 & 1.74 & & -3.566 & * \\
\hline Cooler shrink (\%) & 3.21 & 4.01 & 3.75 & 3.96 & 5.15 & 3.48 & 0.48 & 2.797 & & * \\
\hline Carcass length $(\mathrm{cm})$ & 72.2 & 69.7 & 69.2 & 67.3 & 68.4 & 64.0 & 2.51 & & -3.969 & * \\
\hline Shoulder fat (mm) & 29.5 & 25.3 & 28.8 & 22.5 & 19.2 & 19.3 & 2.08 & & -0.335 & $\star \star \star *$ \\
\hline Eye muscle area $\left(\mathrm{cm}^{2}\right)$ & 15.8 & 14.1 & 13.4 & 13.1 & 10.9 & 11.3 & 1.41 & & -4.189 & $\star *$ \\
\hline Drip loss (\%) & 1.21 & 1.24 & 2.48 & 1.19 & 0.59 & 1.71 & 0.47 & & & NS \\
\hline $\mathrm{pH}_{24}$ & 5.22 & 5.20 & 5.32 & 5.14 & 5.26 & 5.34 & 0.16 & & & NS \\
\hline
\end{tabular}

${ }^{\star \star \star} P<0.001 ;{ }^{\star \star} P<0.01 ;{ }^{\star} P<0.05$; NS: not significant; SEM: standard error of mean 
Table 3 Relationship between inclusion levels of potato hash silage and primal pork cuts measurements of slow-growing Windsnyer pigs

\begin{tabular}{|c|c|c|c|c|c|c|c|c|c|c|}
\hline \multirow{2}{*}{ Variable } & \multicolumn{6}{|c|}{ Silage inclusion level } & \multirow{2}{*}{ SEM } & \multicolumn{2}{|c|}{ Regression co-efficient } & \multirow{2}{*}{$\begin{array}{c}\text { Polynomial regression } \\
\text { Significance levels }\end{array}$} \\
\hline & 0 & 80 & 160 & 240 & 320 & 400 & & Quadratic & Linear & \\
\hline $\mathrm{HQL}(\mathrm{cm})$ & 31.0 & 32.0 & 33.3 & 34.3 & 41.4 & 27.2 & 2.81 & 0.089 & & * \\
\hline $\mathrm{HQC}(\mathrm{cm})$ & 45.7 & 44.2 & 40.7 & 42.5 & 33.6 & 39.5 & 2.72 & & -0.699 & * \\
\hline DFT1 (mm) & 16.7 & 17.2 & 21.2 & 18.8 & 16.2 & 12.3 & 2.48 & & & NS \\
\hline DFT2 (mm) & 18.7 & 18.0 & 18.3 & 16.0 & 16.2 & 14.0 & 1.71 & & -0.269 & * \\
\hline DFT3 (mm) & 19.0 & 20.1 & 19.3 & 17.8 & 14.2 & 15.3 & 1.65 & & -0.876 & * \\
\hline HQWP (\%) & 18.5 & 19.5 & 22.4 & 21.3 & 20.8 & 19.2 & 1.33 & & & NS \\
\hline RWP (\%) & 7.89 & 7.44 & 10.2 & 8.15 & 7.84 & 7.62 & 0.81 & & & NS \\
\hline SWP (\%) & 11.7 & 11.7 & 14.2 & 11.9 & 12.3 & 12.3 & 0.86 & & & NS \\
\hline
\end{tabular}

${ }^{\star \star \star} P<0.001 ;{ }^{* \star} P<0.01 ;{ }^{*} P<0.05$; ns not significant. HQL: hindquarter length; HQC: hindquarter circumference; DFT1: dorsal fat thickness at first rib; DFT2: dorsal fat thickness at last rib; DFT3: dorsal fat thickness at last lumbar vertebra; HQWP: hindquarter weight proportion; RWP: rib weight proportion; SWP: shoulder weight proportion

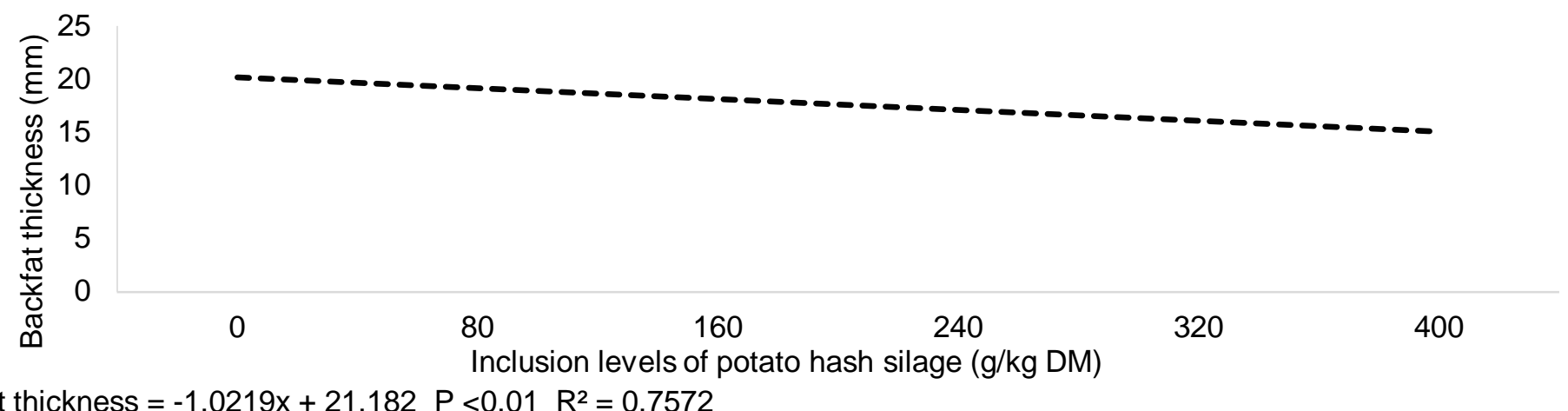

Backfat thickness $=-1.0219 x+21.182 P<0.01 R^{2}=0.7572$

Figure 1 Relationship between inclusion levels of potato hash silage and backfat thickness 
When pigs become frustrated, alkaline phosphatase becomes high. High levels of testosterone hormone in Windsnyer pigs since they attain puberty early could also be a plausible explanation for increasing alkaline phosphatase. The positive response in the activity of alkaline phosphatase was slightly below normal range (Radostits et al., 2000; Kanengoni et al., 2015). This indicates that increasing levels of ensiled silage could have a negative impact on the liver function of pigs.

It is important to understand the efficiency of Windsnyer pigs to convert local feed resources, such as silage, into pork products. A negative linear response in warm carcass weight, cold carcass weight and dressing percentage could mean Windsnyer pigs were less efficient at utilizing the diets containing silage. Likewise, Moset et al. (2015) reported a linear decrease in the carcass yield of pigs when fed a diet containing ensiled citrus pulp. Cooler shrinkage is the weight loss that occurs as the carcass loses moisture during chilling. A positive quadratic relationship between cooler shrink and inclusion levels of silage is difficult to explain. A positive quadratic response in cooler shrink could also be associated with decreases in DFT2 and DFT3. Carcasses with excessive amounts of fat are likely to have less cooler shrink than trimmer carcasses (Latorre et al., 2003). A negative linear response in fat content in the carcass has a positive impact on the cooler shrink. The negative linear relationship between carcass length and inclusion of silage is difficult to justify. Generally, Windsnyer pigs have short carcass stature (Kanengoni et al., 2014; Madzimure et al., 2017). Carcass length is influenced mostly by genetic selection instead of diet. Windsnyer pigs have a small frame and stocky body, which influence carcass length. Carcass length affects the weights of the most important pork cuts and determines the number of rashers of back bacon that are obtained. Pork from the shoulder is not regarded as one of the leaner cuts of meat because it is high in saturated fat. A negative linear response in shoulder fat could be owing to differences in the slaughter weight of pigs.

Dietary fibre alleviates the weight gain of pigs partly because of its effect in reducing the energy density of the diet (Ndou et al., 2013). A negative linear response in backfat thickness with inclusion levels of silage is probably because the silage reduces nutrient digestion (Thomas et al., 2012) and the absorption of fatty acids. Fang et al. (2014) reported that high dietary fibre and resistant potato starch decreased lipogenesis in the adipose tissue. A negative linear response in HQC could be because Windsnyer pigs have stocky bodies with small distribution of muscle and fat in their hind legs. A positive quadratic response in $\mathrm{HQL}$ is difficult to relate it to inclusion level of silage, but could be related to the carcass length and weight of the pigs. Inclusion of silage in diets did not negatively affect HQWP, RWP and SWP. These primal pork cuts are of economic importance in the South African pork production industry. Silage is a promising feed resource for pigs. The responses in nutrition-related blood metabolites and carcass characteristics of Windsnyer pigs fed silage were reported for the first time in the current study. However, the results were linear rather than quadratic. This makes it difficult to perform statistical analyses to determine the optimum inclusion of silage in the diet without compromising healthiness and carcass yield. Research on the carcass and pork quality of Windsnyer pigs has received little attention because of the need to sacrifice many pigs for research, yet their population is diminishing. The limited number of purebred Windsnyer pigs also compromised the number of replications in the study.

\section{Conclusions}

The relationship between potato hash silage and nutritionally related blood metabolites in growing Windsnyer pigs is equivocal. The albumin exhibited a negative linear relationship and globulin showed a positive quadratic relationship. Inclusion levels of silage did not affect total protein and uric acid. Alkaline phosphatase had a positive linear relationship with inclusion levels of silage. There was a positive relationship between inclusion levels of silage and warm carcass weight, cold carcass weight and dressing percentage. However, there was no clear relationship between other carcass traits and primal pork cuts and silage. Backfat thickness was negatively related to inclusion levels of silage. There is a need to determine the optimum inclusion level of silage in the diet without hindering healthiness and carcass yield in Windsnyer pigs.

\section{Acknowledgements}

The authors wish to recognise the Agricultural Research Council, Professional development Programme, National Research Foundation, Scarce skills development fund and Gauteng Department of Agriculture and Rural Development for funding the project.

\section{Authors' Contributions}

CNN did data collection, statistical analyses and writing up of the first draft of the manuscript. ATK edited the manuscript and contributed with ideas to the development of the project and is a co-supervisor of the project. MC conceived the idea, had an input in writing of the manuscript and is main leader of the project. 


\section{Conflict of Interest Declaration}

There is no conflict of interest among the authors. They also wish to disclose that the funders of the projects did not influence the outcomes of the research findings.

\section{References}

Association of Official Analytical Chemists (AOAC). Official methods of analysis. Eighteenth edition. AOAC International, Gaithersburg, Maryland, USA, 2005.

Canibe, N. \& Bach Knudsen, K.E., 2002. Degradation and physicochemical changes of barley and pea fibre along the gastrointestinal tract of pigs. J. Sci. Food Agric. 82, 27-39.

Cantwell, M., 1996. A review of important facts about potato glycoalkaloids. Perishables Handling Newslett. 87, 26-27.

Carter, N.A., Dewey, C.E., Thomas, L.F., Lukuyu, B., Grace, D. \& De Lange, C., 2016. Nutrient requirements and lowcost balanced diets, based on seasonally available local feedstuffs, for local pigs on smallholder farms in Western Kenya. Trop. Anim. Health Prod. 48, 337.

Chimonyo, M., Kanengoni, A.T. \& Dzama, K., 2001. Influence of maize cob inclusion level in pig diets on growth performance and carcass traits of Mukota $x$ Large White F1 crossbred male pigs. Asian-Australas. J. Anim. Sci. 14, 1724-1727.

Fang, L., Jiang, X., Su, Y. \& Zhu, W., 2014. Long-term intake of raw potato starch decreases backfat thickness and dressing percentage, but has no effect on the longissimus muscle quality of growing-finishing pigs. Livest. Sci. 170, 116-123.

Gous, R.M. \& Morris, T.R., 1985. Evaluation of a diet dilution technique for measuring the response of broiler chickens to increasing concentrations of lysine. Br. Poult. Sci. 26, 147-161.

Halimani, T.E., Muchadeyi, F.C., Chimonyo, M. \& Dzama, K., 2012. Opportunities for conservation and utilisation of local pig breeds in low-input production systems in Zimbabwe and South Africa. Trop. Anim. Health. Prod. 45, 81-90.

Hlatini, V.A. \& Chimonyo, M., 2016. Nutritionally related blood metabolites and liver enzymes in growing pigs fed on Acacia tortilis treated with polyethylene glycol. Livest. Sci. 187, 158-161.

Kanengoni, A.T., Chimonyo, M., Erlwanger, K.H., Ndimba, B.K. \& Dzama, K., 2014. Growth performance, blood metabolic responses, and carcass characteristics of grower and finisher South African Windsnyer-type indigenous and Large White $x$ Landrace crossbred pigs fed diets containing ensiled corncobs. J. Anim. Sci. 92, 5739-5748.

Kanengoni, A.T., Chimonyo, M., Ndimba, B.K. \& Dzama, K., 2015. Feed preference, nutrient digestibility and colon volatile fatty acid production in growing South African Windsnyer-type indigenous pigs and Large White $x$ Landrace crosses fed diets containing ensiled maize cobs. Livest. Sci. 171, 28-35.

Khanyile, M., Ndou, S.P. \& Chimonyo, M., 2017. Influence of Acacia tortilis leaf meal-based diet on serum biochemistry, carcass characteristics and internal organs of finishing pigs. Anim. Prod. Sci. 57, 675-682.

Kyriazakis, I. \& Emmans, G.C., 1995. The voluntary feed intake of pigs given feeds based on wheat bran, dried citrus pulp and grass meal, in relation to measurements of feed bulk. Br. J. Nutr. 73, 191-207.

Latorre, M.A., Medel, P., Fuentetaja, A., Lázaro, R. \& Mateos, G.G., 2003. Effect of gender, terminal sire line and age at slaughter on performance, carcass characteristics and meat quality of heavy pigs. Anim. Sci. 77, 33-45.

Madzimure, J., Chimonyo, M., Hugo, A., Bakare, A.G., Katiyatiya, C.L.F \& Muchenje, V., 2017. Physico-chemical quality attributes and fatty acid profiles of pork from Windsnyer and Large White gilts. S Afr. J. Anim. Sci. 47, 107-114.

McDonald, P., Edwards, R.A., Greenhalgh, J.F.D., Morgan, C.A., Sinclair, L.A. \& Wilkinson, R.G., 2010. Animal nutrition. 7th edition. Pearson, London, UK. pp. 479-607.

Moset, V., Piquer, O., Cervera, C., Fernández, C.J., Hernández, P. \& Cerisuelo, A., 2015. Ensiled citrus pulp as a byproduct feedstuff for finishing pigs: Nutritional value and effects on intestinal microflora and carcass quality. Span J. Agric. Res. 13, 0607.

Ncobela C.N., Kanengoni, A.T., Thomas, R.S. \& Chimonyo, M., 2018. Voluntary feed intake and growth performance of slow-growing pigs fed on ensiled potato hash silage meal. Trop. Anim. Health. 50, 113-120.

Ncobela, C.N., Kanengoni, A.T., Hlatini, V.A., Thomas, R.S. \& Chimonyo, M., 2017. A review of the utility of potato byproducts as a feed resource for smallholder pig production. Anim. Feed Sci. Technol. 227, 107-117.

Ndou, S.P., Gous, R.M. \& Chimonyo, M., 2013. Prediction of scaled feed intake in weaner pigs using physico-chemical properties of fibrous feeds. Br. J. Nutr. 110, 774-780.

Nkosi, B.D. \& Meeske, R., 2010. Effects of whey and molasses as silage additives on potato hash silage quality and growth performance of lambs. S. Afr. J. Anim. Sci. 40, 229-237.

Radostits, O.M., Gay, C.C., Blood, D.C. \& Hinchcliff, K.W., 2000. Veterinary medicine. 9th edition. W.B. Saunders, London, pp.1819-1822.

SAS, 2008. SAS user's guide: Statistics, Version 9.1.SAS Institute, Cary, NC, USA.

Schweihofer, J.P., 2011. Carcass dressing percentage and cooler shrink vary among species and type of animals. Michigan State University.

Thomas, R., Nkosi, B.D., Kanengoni, A.T., Umesiobi, D.O. \& Makgothi, O.G., 2012. Effects of different dietary inclusion levels of ensiled potato hash on nutrient digestibility in pigs. J. Anim. Sci. Adv. 2, 216-220.

Van Soest, P.V., Robertson, J.B. \& Lewis, B.A., 1991. Methods for dietary fiber, neutral detergent fiber, and nonstarch polysaccharides in relation to animal nutrition. J. Dairy Sci. 74, 3583-3597.

Weichselbaum, T.E., 1946. An accurate and rapid method for the determination of proteins in small amounts of blood serum and plasma. Am. J. Clin. Pathol. 10, 40-49.

Whittemore, E.C., Emmans, G.C. \& Kyriazakis, I., 2003. The relationship between live weight and the intake of bulky foods in pigs. Anim Sci. 76, 89-10. 
Zanga, J., Chimonyo, M., Kanengoni, A., Dzama, K. \& Mukaratirwa, S., 2003. A comparison of the susceptibility of growing mukota and large white pigs to infection with ascaris suum. Vet. Res. Commun. 27, 653-660.

Zhang, H.J., Xiong, Z.Y., Zuo, B., Lei, G.M., Jiang, W.S., Li, E.F., Zheng, R.L., Li, J. \& Xu, Q.D., 2007. Quantitative trait loci for carcass traits on pig chromosomes 4, 6, 7, 8 and 13. J. Appl. Genet. 48, 363-366. 